\title{
Dominance of a coral community by the genus Porites (Scleractinia)
}

\author{
D. C. Potts ${ }^{1}$, T. J. Done ${ }^{2}$, P. J. Isdale ${ }^{2} \&$ D. A. Fisk ${ }^{2}$ \\ ${ }^{1}$ Biology Department and Center for Marine Studies, University of California, Santa Cruz, California 95064, USA \\ ${ }^{2}$ Australian Institute of Marine Science, P. M. B. No. 3, Townsville, M. C., Queensland 4810, Australia
}

\begin{abstract}
The genus Porites is a major component of many coral communities on inshore continental shelf reefs of the Great Barrier Reef. On the leeward margin of Pandora Reef, 7 species of massive Porites physically dominate the coral community. The populations of commoner species are themselves dominated, demographically and genetically by a few persistent genotypes. Five \% of colonies contain $52 \%$ of skeletal $\mathrm{CaCO}_{3} ; 9 \%$ of colonies have $50 \%$ of living tissues. The largest colony is at least $677 \mathrm{yr}$ old. Genotypic ages of tissues may be considerably greater, since colonies appear to form clones by fragmentation.
\end{abstract}

\section{INTRODUCTION}

Descriptions of coral reefs often mention very large colonies, sometimes with speculation about their ages (e.g. Wells 1957, Goreau et al. 1972), but the ecological, evolutionary and structural implications of large size and extreme longevity are rarely discussed (but see Highsmith 1982). Some coral communities of the Great Barrier Reef contain numerous large and presumably old colonies of Porites. Such communities are especially common on leeward margins of nearshore platform and fringing reefs (or inner-shelf reefs), and they also occur on some mid-shelf and outer-shelf reefs (Done 1982).

A good example exists on the leeward side of Pandora Reef (Fig. 1) where size of some individuals approach those of the largest colonies of any species observed throughout the Great Barrier Reef region ( $T$. J. Done pers. obs.). Consequently, longevities of individual colonies and genotypes at this site may approach the maximum values likely to be achieved in any extant coral population. If this is the case, the site is appropriate for evaluating some assumptions of a recent model of coral evolution (Poots 1983, 1984). This model suggests that rates of population differentation, including speciation, among shallow-water corals have been reduced during Pliocene-Pleistocene sea

Contribution No. 257 of the Australian Institute of Marine Science level fluctuations. It is proposed that small numbers of large, old genotypes could dominate populations to such an extent that those populations would not experience sufficient numbers of generations for completion of directional evolutionary processes during the persistence of particular habitats at a given sea level.

The major objective of this study was examination of the structure of the Porites community on Pandora Reef to assess the extent of ecological dominance, and to determine whether any individuals have the potential to dominate their populations for extended periods. We describe size distributions in a community containing 7 species of Porites. We assess the relative contributions of larger colonies to skeletal mass and total biomass, and use preliminary data on size-age relationships to estimate minimum ages of large colonies.

\section{SITE AND METHODS}

Pandora Reef $\left(18^{\circ} 52^{\prime} \mathrm{S}, 146^{\circ} 25^{\prime} \mathrm{E}\right)$ is a small platform reef lying $16 \mathrm{~km}$ offshore, approximately halfway between the Australian mainland and the Palm Islands (Fig. 1). It is about $1.0 \times 0.5 \mathrm{~km}$ and is surrounded by turbid waters with a maximum depth of about $20 \mathrm{~m}$. The main east-west axis is an elevated rubble ridge that is submerged tidally (Hamner \& Hauri 1981, Hopley 1982). Prevailing winds are the southeast trades. For approximately $500 \mathrm{~m}$ along the northern 


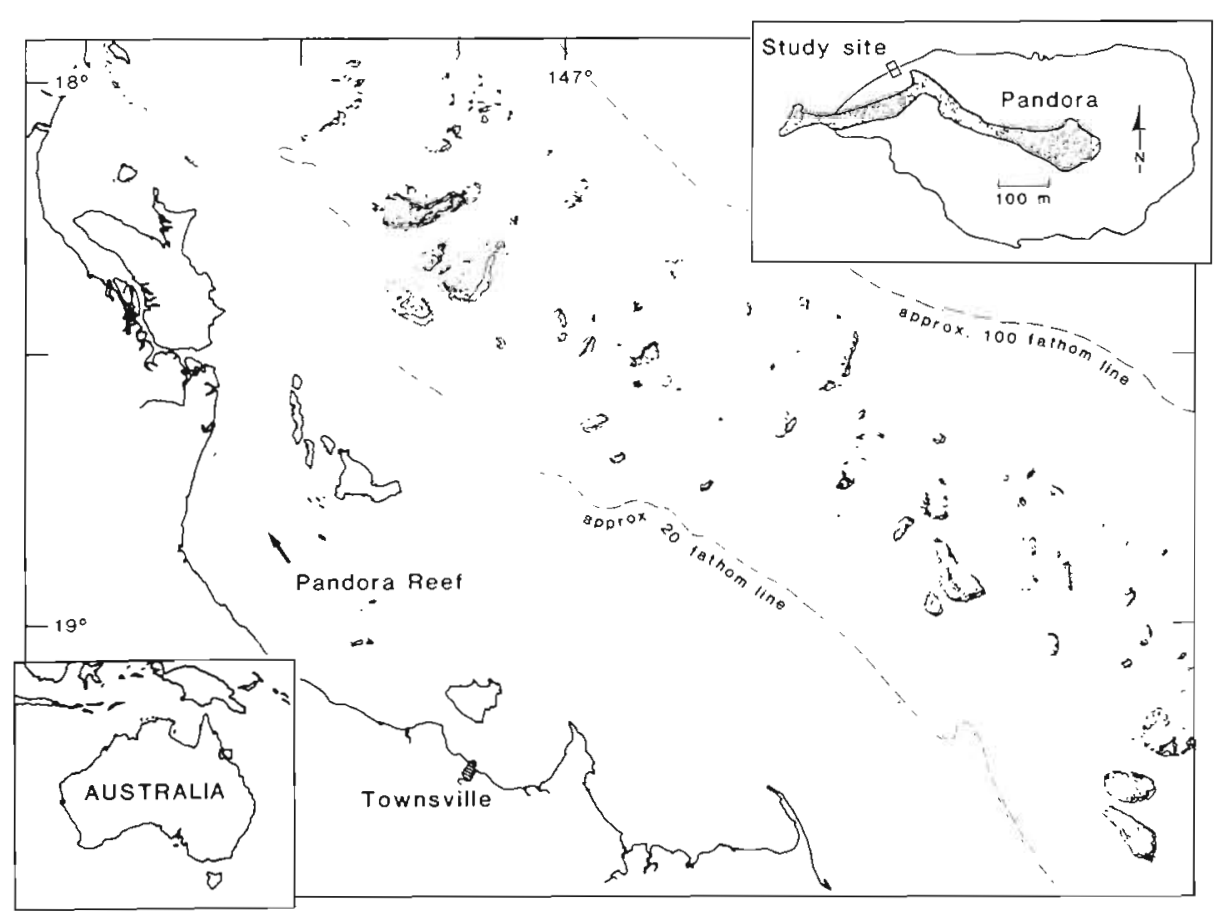

Fig. 1. Locations of Pandora Reef and study site. Stippled area of upper inset is emergent rubble cey leeward margin of the reef, the coral community consists mainly of massive colonies of Porites. These corals form the entire front of the reef, extending from the intertidal outer reef flat down to the base of the reef slope at about 4 to $5 \mathrm{~m}$ depth. Other coral genera constitute a very small proportion of total scleractinian biomass at the site and are not considered in this paper.

The study site was a $30 \times 12 \mathrm{~m}$ plot plus a small contiguous area, totalling $385 \mathrm{~m}^{2}$, and extending from the reef flat to the sea floor (Fig. 2). In December 1982, the plot was marked with steel posts and a numbered plastic tag was nailed to the top of each colony. All colonies were sketched, measured and mapped in 3dimensions using a trilateration procedure based on Fryer \& Done (1982). The percent living surface area was estimated visually for each colony and a specimen was collected from each for species identification (Veron \& Pichon 1982). Average diameter, volume, total surface area and live surface area of each colony were estimated by geometric approximation. Most colonies were assumed to be half ellipsoids with their vertical axes being the longest. Some flat-topped colonies and micro-atolls were treated as cylinders.

Ages of 4 colonies were estimated from colony dimensions and recent growth rates. Mean annual growth rates were estimated from surface cores (10 to $15 \mathrm{~cm}$ long) taken with a $27 \mathrm{~mm}$ diameter hole saw welded to a $30 \mathrm{~cm}$ pipe and mounted in a pneumatic drill. Annual growth increments were measured by standard X-radiographic procedures (Buddemeier et al. 1974, Isdale 1977). Colony ages were estimated, assuming mean growth rates had remained constant during the life of the colony. This assumption is supported by data from long cores (Druffel 1982, Isdale 1984). The minimum age (A) of each colony was estimated, assuming faster than average growth rates, using the formula

$$
A=T /(I+2 \text { S.E. })
$$

where $\mathrm{T}=$ length of most probable trajectory of growth from the centre of the base of the colony to the most distant point on its surface; I = mean annual radial growth increment; $\mathrm{S}$. E. = standard error of growth increment.

\section{RESULTS}

Locations and plan shapes of each colony are shown in Fig. 2, lower. The total projected area of Porites in the mapped area is approximately $246 \mathrm{~m}^{2}$, or about $64 \%$ of the plan area. A 3 -dimensional reconstruction of the plot (Fig. 2, upper) shows the colonies of Porites projecting upwards from a gentle slope of mud, sand and coral rubble. The 3 largest colonies have dead, horizontal tops that are exposed at low tide. Estimates of dimensions, volumes and surface areas of colonies were made only for those parts above the sediments, since no information is available on the extent to which basal portions of colonies may be buried by surrounding sediments. Altogether, there are $257 \mathrm{~m}^{3}$ of $\mathrm{CaCO}_{3}$ with a total surface area of $456 \mathrm{~m}^{2}$, of which approximately $38 \%$ is covered with living Porites tissues. 


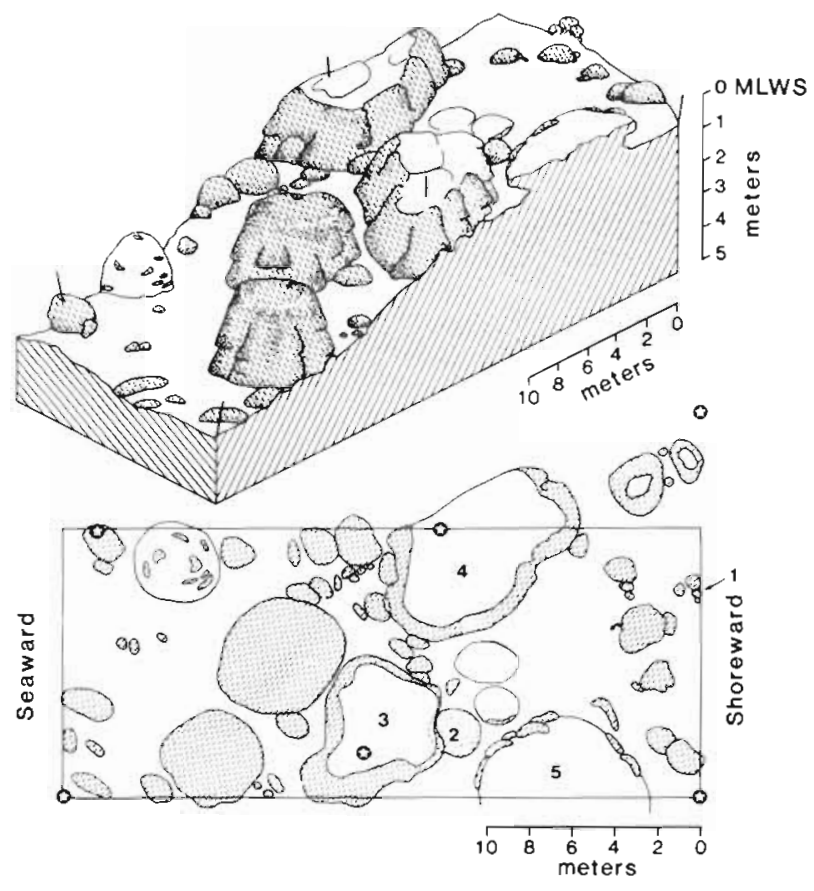

Fig. 2. Upper: 3-dimensional reconstruction and (lower) plan view of the mapped area. Stars: permanent stakes. Living surfaces of colonies of Porites stippled, dead portions blank. Ages of Colonies 1 to 4 estimated. Isolated small colonies attached to the edges of Colony 5 are treated separately although they may be surviving remnants of the large colony

Sixty-five colonies belonging to 7 species of Porites are wholly or partially contained within the mapped area, and the contributions of each species are indicated in Table 1 . The assemblage is dominated by $P$. lobata, which has $60 \%$ of individuals and provides 70 to $79 \%$ of total volume and surface area. P. lutea ranks third numerically $(12 \%)$ but second by other criteria, accounting for 11 to $22 \%$ of volume and surface area. The numerically second ranking $P$. solida $(15 \%)$ provides only 5 to $8 \%$ of material. The 4 remaining species together provide $12 \%$ of colonies but only 0.7 to $2.2 \%$ of volume and area.
Table 1 also includes size ranges and median sizes for each species, while Fig. 3 summarizes size frequency distributions. The general form of the size frequency distributions is similar for Porites lobata and the other species. Most colonies are smaller than $1.5 \mathrm{~m}$ diameter, but $P$. lobata, $P$. solida and $P$. lutea have colonies $\geqslant 3.0 \mathrm{~m}$ diameter, and all the species except $P$. murrayensis are known to grow into large colonies (Veron \& Pichon 1982). The median diameter for $P$. lobata ( $\simeq 1.1 \mathrm{~m}$ diameter) is more than twice that of the other species $(0.49 \mathrm{~m})$.

Disproportionate amounts of skeletal calcium carbonate and biomass are contributed to the community by a few large colonies. Among the 65 colonies measured, the 3 largest ( $\geqslant 4.9 \mathrm{~m}$ diameter) contain $52 \%$ of total $\mathrm{CaCO}_{3}$ while only 12 colonies ( $\geqslant 1.85 \mathrm{~m}$ diameter) provide $91 \%$ of skeletal material. Similarly, $50 \%$ of living surface area comes from only 6 colonies, while $90 \%$ of tissues is contained in 31 colonies ( $48 \%$ numerically). Dominance of biomass (living area) is less pronounced than of volume because the largest colonies have extensive dead areas resulting from exposure at low tide or from smothering by accumulating sediments.

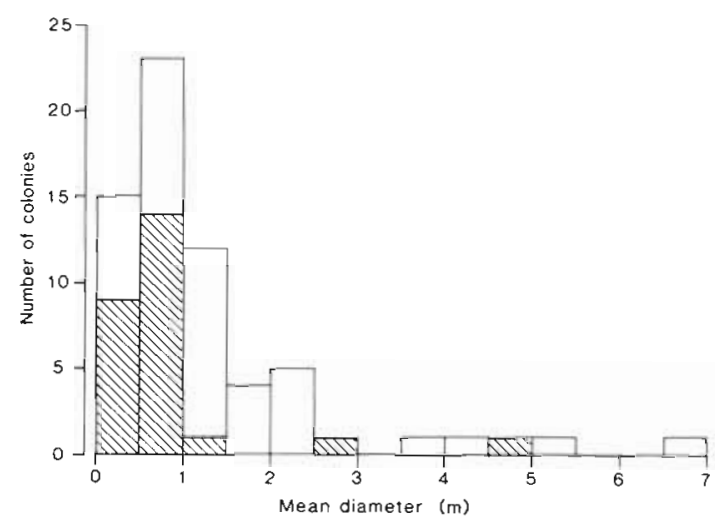

Fig. 3. Size-frequenzy distributions of Porites at Pandora Reef, P. lobata colonies blank $(\mathrm{N}=39)$; other Porites species stippled $(\mathrm{N}=26)$

Table 1. Colony sizes and relative contributions of 7 species of Porites, ranked by numerical abundance, on the Pandora Reef study site

\begin{tabular}{|c|c|c|c|c|c|c|}
\hline \multirow[b]{2}{*}{ Species } & \multirow[b]{2}{*}{$\begin{array}{l}\text { No. of } \\
\text { colonies }\end{array}$} & \multicolumn{2}{|c|}{ Colony diameters (m) } & \multicolumn{3}{|c|}{ Relative contributions } \\
\hline & & Range & Median & Volume & $\begin{array}{l}\text { Surface } \\
\text { area }\end{array}$ & $\begin{array}{c}\text { Live surface } \\
\text { area }\end{array}$ \\
\hline Totals & 65 & $0.20-6.85$ & 0.90 & $257.1 \mathrm{~m}^{3}$ & $455.8 \mathrm{~m}^{2}$ & $173.5 \mathrm{~m}^{2}$ \\
\hline P. lobata & 39 & $0.20-6.85$ & 1.10 & .7786 & .7905 & .7008 \\
\hline P. solida & 10 & $0.25-3.00$ & 0.65 & .0602 & .0750 & .0586 \\
\hline P. Iutea & 8 & $0.35-4.90$ & 0.68 & .1546 & .1148 & .2181 \\
\hline P. australiensis & 4 & $0.30-1.40$ & 0.48 & .0061 & .0164 & .0165 \\
\hline P. mayeri & 2 & $0.30-0.60$ & 0.45 & .0003 & .0019 & .0043 \\
\hline P. murrayensis & 1 & 0.45 & 0.45 & .0002 & .0013 & .0017 \\
\hline P. annae & 1 & 0.20 & 0.20 & $<.0001$ & $<.0001$ & $<.0001$ \\
\hline
\end{tabular}


Table 2. Annual growth increments and estimated minimum ages of 4 colonies of Porites

\begin{tabular}{|c|c|c|c|c|c|c|}
\hline No: & Species & $\begin{array}{c}\text { Average } \\
\text { diameter } \\
\text { (m) }\end{array}$ & $\begin{array}{l}\text { Annual growth } \\
\text { increments (mm) } \\
\bar{X} \pm S E\end{array}$ & $\begin{array}{l}\text { Longest growth } \\
\text { trajectory } \\
\text { (mm) }\end{array}$ & $\begin{array}{l}\text { Maximum } \\
\text { growth rate } \\
\left(\mathrm{nm} \mathrm{yr}^{-1}\right)\end{array}$ & $\begin{array}{c}\text { Minimum } \\
\text { colony age } \\
\text { (yr) }\end{array}$ \\
\hline 1 & P. solida & 0.3 & $12.38 \pm 1.28$ & 471 & 14.94 & 32 \\
\hline 2 & P. lobata & 2.2 & $12.52 \pm 0.87$ & 1728 & 14.26 & 121 \\
\hline 3 & P. lobata & 5.5 & $7.55 \pm 0.25$ & 3456 & 8.05 & 429 \\
\hline 4 & P. lobata & 6.85 & $8.67 \pm 0.33$ & 6313 & 9.33 & 677 \\
\hline \multicolumn{3}{|c|}{ Annual means } & 10.28 & \multicolumn{3}{|c|}{11.65} \\
\hline \multicolumn{7}{|c|}{ - Numbered as in Fig. 2b } \\
\hline \multicolumn{7}{|c|}{ - Assuming maximum sustained growth rate $=$ mean annual increment +2 SE throughout the life of the colony } \\
\hline
\end{tabular}

The average growth rate of about $10.3{\mathrm{~mm} \mathrm{yr}^{-1}}^{-1}$ (Table 2) is consistent with growth rates of massive Porites obtained elsewhere on the central Great Barrier Reef (Isdale 1977, 1984) and at Enewetak (Highsmith 1979). While Table 2 suggests that large colonies may grow more slowly than smaller ones, this conclusion is probably an artefact of small sample size. Other samples from Pandora Reef indicate large and small Porites have similar ranges of growth rates (P. J. Isdale unpubl.). However, the morphology of the largest colonies (Colonies 3 and 4 , Table 2) is very different from most others in the survey (Fig. 2) because the former are large, flat topped platforms with dead tops at low water mark with their live tissues restricted to vertical walls. Most other colonies (including 1 and 2, Table 2) are hemiellipsoidal domes with live tissues over the entire surface.

The growth rates in Table 2 indicate that the largest colony is at least $677 \mathrm{yr}$ old and that the sriallest colony on the site $(0.2 \mathrm{~m}$ diameter) is at least 10 to $20 \mathrm{yr}$ old. No smaller individuals were found within the plot despite intensive searching, which suggests that successful establishment of new individuals by larval recruitment has not occurred during that time. This time span may underestimate minimum colony age, because many small colonies have dead portions extending an unknown distance into the sediments.

Some smaller colonies ( $<1.0$ diameter) appear to be lobes that have broken off large colonies, for example, around the edges of Colony 5 and in the gutter between Colonies 3 and 4 (Fig. 2b). This suggests asexual fragmentation of larger colonies may be an important source of new colonies. Fragmentation in Porites has also been described by Highsmith (1980, 1982), Kojis \& Quinn (1981) and Dollar (1982).

\section{DISCUSSION}

The community on the leeward margin of Pandora Reef is characterized by 5 types of dominance - genus, species, colony, genotype and gamete. Collectively, they indicate that relatively few genotypes strongly influence local reef processes. First, both the physical structure of the reef and the living coral community are composed almost entirely of a single genus, Porites. Second, although the Porites assemblage contains several species, the plot is dominated by one species, $P$. lobata, that provides almost $80 \%$ of the physical mass, $70 \%$ of living tissues and $60 \%$ of colonies (Table 1 ). Ecologically, the minor species seem very similar to $P$. lobata, since they live in the same habitat and, like $P$. lobata, they tend to grow into massive, hemispherical to hemi-ellipsoidal colonies. Third, a few individual colonies dominate the system: out of 65 colonies, only 3 (2 $P$. lobata) provide half the skeletal mass, while 6 colonies (4 $P$. lobata) contain half the living tissue. Fourth, the apparent absence of successful larval recruitment and the inferred establishment of new colonies via fragmentation suggest that dominance by particular genotypes may be even more pronounced than by individual colonies. After fragmentation, tissues derived from a single zygote will be distributed among several discrete colonies collectively forming a clone that may be both larger and older than even the largest single colony. If large colonies at Pandora Reef were themselves founded from fragments of large, preexisting colonies, the genotypic ages of tissues could be several times the estimated ages of living colonies.

A fifth kind of dominance, of the pool of gametes in each breeding season, may also occur at the site. Since polyps tend to reproduce simultaneously and throughout a colony of Porites (Kojis \& Quinn 1981), the live surface area of a colony provides an index of its reproductive output and of its relative contribution to future generations. Thus the 6 colonies that make up $50 \%$ of total living tissues (all over $1.85 \mathrm{~m}$ diameter, with estimated minimum ages from about 120 to $677 \mathrm{yr}$ ) presumably contribute about $50 \%$ of the gametes produced each year. Within particular species, gametic dominance may be even more pronounced. Among the 
eight colonies of $P$. lutea, a single colony contributes $82 \%$ of tissues and, presumably, gametes, while $18 \%$ of colonies provide half the reproductive output of $P$. lobata. Should any of these colonies be clonemates, the relative contributions of those genotypes would be even greater.

The consequences of gametic dominance depend on modes of sexual reproduction and patterns of larval dispersal, especially the extent to which planktonic larvae remain on the parental reef. Mode of reproduction is known for 4 of the Porites species at the study site. Only $P$. murrayensis is known to brood larvae that are likely to settle near their parents shortly after release (Kojis \& Quinn 1981). Three species ( $P$. lobata, $P$. lutea, $P$. australiensis) have external fertilization (Kojis \& Quinn 1981, Harriott 1983) with the embryos remaining planktonic for perhaps 36 to $48 \mathrm{~h}$ (A. Heyward pers. comm.). In theory, this is sufficient time for dispersal to neighbouring reefs. With extensive exchange between reefs, corals over large areas may behave effectively as a panmictic population and the gametic dominance at one site is unlikely to be perpetuated in the genetic structure of succeeding age classes. However, physical processes which may inhibit inter-reef dispersal of larvae have been described. These include the separation of oceanic and reef waters, and the retention of surface reef waters by eddies and vortices (Hamner \& Hauri 1977, 1981, Poots \& Swart 1984). In such situations larvae may settle close to their parents and gametic dominance will be reflected in the genotypes of juveniles.

Each kind of dominance appears to be a consequence of individual longevity, low turnover rates in the community and prolonged persistence of the physical and biological entities. Our estimated minimum age ( $677 \mathrm{yr}$ ) for the largest colony at the site is considerably greater than the maximum reliable ages reported (to date) for living corals of about $200 \mathrm{yr}$ (Nozaki et al. 1978) and 350 yr (Druffel 1982). In neither of these studies (based on analysis of cores from single colonies) was there any indication of how representative these colonies were of the populations.

We conclude that the Porites populations on Pandora Reef possess some of the properties assumed by the model of Potts $(1983,1984)$ in which it was proposed that prolonged generations inhibit population differentiation. A small number of colonies and genotypes can make disproportionately large contributions to the physical, demographic and genetic structures of the populations. Some of the Porites colonies have certainly existed for centuries, the largest colonies may approach $700 \mathrm{yr}$ and some genotypes might be much older.

Rates of evolutionary change are commonly expressed in terms of mean generation time, defined as the average age of mothers after birth of half their progeny (Charlesworth 1980). Recent models of clonal organisms with indeterminate growth suggest that mean generation times in such organisms may approach the age of the largest genotypes (Levin 1978, S. R. Palumbi unpubl.). Consequently, Porites populations on Pandora Reef could have experienced, theoretically, as few as 10 generations since the sea reached present levels, about 7000 yr ago. While these findings are consistent with assumptions of the model (Potts 1983, 1984), the evolutionary significance of the existence of such populations cannot yet be assessed. Continuing studies at an expanded site on Pandora Reef will determine the genotypic identity of each colony, and then examine ecological, demographic and genetic properties of the populations in greater detail, with the goal of partially reconstructing the biological history of the site during the Holocene.

Acknowledgements. We thank J. E. N. Veron for identification of corals, and L. R. Fox, J. S. Pearse and M. W. Silver for their comments on the manuscript. We thank the crew of the R. V. 'Sirius' for field support. D. C. P. thanks Dr. J. S. Bunt for making available the resources of the Australian Institute of Marine Science, and thanks the Faculty Research Committee of the University of California, Santa Cruz for travel support.

\section{LITERATURE CITED}

Buddemeier, R. W., Maragos, J. E., Knutson, D. W. (1974). Radiographic studies of reef coral exoskeletons: rates and patterns of coral growth. J. exp. mar. Biol. Ecol. 14: $179-200$

Charlesworth, B. (1980). Evolution in age-structured populations. Cambridge Univ. Press, Cambridge

Dollar, S. (1982). Wave stress and coral community structure in Hawaii. Coral Reefs 1: 71-81

Done, T. J. (1982). Patterns in the distribution of coral communities across the central Great Barrier Reef. Coral Reefs 1: $95-107$

Druffel, E. M. (1982). Banded corals: changes in oceanic carbon-14 during the Little Ice Age. Science 218: 13-19

Fryer, J. G., Done, T. J. (1982). An underwater trilateration. Austr. Surveyor 31: 7-12

Goreau, T. F., Lang, T. C., Graham, E. A., Goreau, P. D. (1972). Structure and ecology of the Saipan reefs in relation to predation by Acanthaster planci (Linneaus). Bull mar. Sci. 22: 113-152

Hamner, W. M., Hauri, I. R. (1977). Fine scale surface currents in the Whitsunday Islands, Queensland, Australia: effect to tide and topography. Aust. J. mar. Freshw. Res. 28: 333-359

Hamner, W. M. Hauri, I. R. (1981). Effects of island mass water flow and plankton pattern around a reef in the Great Barrier Reef lagoon, Australia. Limnol. Oceanogr. 26: 1084-1102

Harriott, V. J. (1983). Reproductive ecology of four scleractinian species at Lizard Island, Great Barrier Reef. Coral Reefs 2: 9-18

Highsmith, R. C. (1979). Coral growth rates and environment 
control of density banding. J. exp. mar. Biol. Ecol. 37 : $105-125$

Highsmith, R. C. (1980). Passive colonization and asexual colony multiplication in the massive coral Porites lutea Milne Edwards \& Haime. J. exp. mar. Biol. Ecol. 47: 55-67

Highsmith, R. C. (1982). Reproduction by fragmentation in corals. Mar. Ecol. Prog. Ser. 7: 207-226

Hopley, D. (ed.) (1982). The geomorphology of the Great Barrier Reef: quaternary development of coral reefs. Wiley Interscience, New York

Isdale, P. (1977). Variation in growth rate of hermatypic corals in a uniform environment. Proc. 3rd Int. Coral Reef Symp. 2: $403-408$

Isdale, P. (1984). Fluorescent bands in massive corals record centuries of coastal rainfall. Nature, Lond. 310: 578-579

Kojis, B. L., Quinn, N. J. (1981). Reproductive strategies in four species of Porites (Scleractinia). Proc. 4th Int. Coral Reef Symp. 2: 145-151

Levin, D. A. (1978). Some genetic consequences of being a plant. In: Brussard, P. F. (ed.). Ecological genetics: the interface. Springer-Verlag, Heidelberg, p. 189-212

Nozaki, Y., Rye, D. M., Turekian, K. K., Dodge, R. E. (1978). A 200 year record of carbon-13 and carbon-14 variations in a Bermuda coral. Geophys. Res. Lett. 5: 825-828

Potts, D. C. (1983). Evolutionary disequilibrium among IndoPacific corals. Bull. mar. Sci. 33: 619-632

Potts, D. C. (1984). Generation times and the Quaternary evolution of reef-building corals. Paleobiology 10: 48-58

Potts, D. C., Swart, P. K. (1984). Water temperature on a coral reef as an indicator of environmental variability. Limnol. Oceanogr. 29: 504-516

Veron, J. E. N., Pichon, M. (1982). Scleractinia of eastern Australia. Part. IV. Family Poritidae. Aust. Inst. Mar. Sci. Monogr. Ser. 5: 1-159

Wells, J. W. (1957). Coral Reefs. In: Hedgpeth, J. W. (ed.) Treatise on marine ecology and paleoecology. Vol. 1. Ecology. The Geological Society of America. (Mem. geol. Soc. Am. 67: (1): 609-631 